\title{
Susceptibility of soybean varieties for mites associated with some biological aspects
}

\author{
Heikal, H. M. and Safaa M. Abo-Taka \\ Economic Entomology \& Agricultural Zoology Dept., Faculty of Agriculture, \\ Menoufia University, Egypt, hanyheikal61@yahoo.com
}

\begin{abstract}
Populations of Tetranychus urticae Koch (Acari: Tetranychidae), and its predatory mite, Agistemus exsertus Gonzalez (Acari: Stigmaeidae), were determined on four soybean varieties during 2016 season, as well as study of some biological aspects for both species was done. The obtained results revealed that Giza 35 variety was the most susceptible variety with significant difference between the mean numbers of $T$. urticae compared with other varieties. The mean of infestation was 11.89 individuals $/ 25 \mathrm{~cm}^{2}$ of leaves, while the mean number of $T$. urticae was 7.11 and 3.54 individuals $/ 25 \mathrm{~cm}^{2}$ of leaves for Giza 111 and Giza 82 without significant difference. Giza 22 recorded the lowest mean number of $T$. urticae 1.53 individuals $/ 25 \mathrm{~cm}^{2}$. The population dynamics of $T$. urticae cleared that infestation increased gradually from mid-June reach its maximum at the end of July then decreased gradually at the beginning of August reach its minimum number at the beginning of September before the harvest time. As for A. exsertus, data showed that the mean number of $A$. exsertus was the highest on Giza 35 (2.46 individuals $/ 25 \mathrm{~cm}^{2}$ ) followed by Giza 22 (2.13 individuals $/ 25 \mathrm{~cm}^{2}$, but Giza 82 and Giza 111 mean numbers were 1.99 , and 1.91 individuals $/ 25 \mathrm{~cm}^{2}$. Life cycle of Tetranychid males was the shortest when reared on Giza 35with significant difference with other varieties. As for females, the shortest life cycle was when reared on Giza 35 with significant difference with Giza 22, which recorded the longest life cycle for males and females respectively.
\end{abstract}

Key words: Soybean varieties, Susceptibility, Tetranychus urticae, Agistemus exsertus, Biological aspects.

\section{INTRODUCTION}

The two-spotted spider mite (Tetranychus urticae) is present in soybean crops every year, but not often a significant problem. The risk of its significant infestation increases considerably during periods of hot weather and prolonged drought. It feeds on various species of plants being a major pest of vegetables, ornamentals, fruit trees, soybean, cotton, beans, etc. (Van de Vrie et al. 1972, Skorupska 2004, Khanjani 2005 \& Martinez-Ferrer et al. 2006). Soybean is an economic important crop in the world, and Egypt ranks $47^{\text {th }}$, commercially produced $(25,000$ ton) according to FAO 2014. The importance of $T$. urticae is not only due to direct injuring to plants including defoliation, leaf burning, and even in excessive outbreaks plant death but also indirect damaging to plants which decreases photosynthesis and transpiration (Brandenburg \& Kennedy 1987).The population growth parameters of T. urticae such as developmental rate, survival, reproduction and longevity can vary in particular with respect to temperature, host plant species, host plant nutrition, cultivar kind, phenological stage, exposure to pesticides, relative humidity, etc. (Sabelis 1981, Brandenburg \& Kennedy 1987, Wermelinger et al. 1991, Wilson 1994, Dicke 2000, James \& Price 2002, Marcic 2003, Skorupska 2004, Ahmadi et al. 2006).

The predatory mite, Agistemus exsertus Gonzalez is an important natural enemy of acarine pests in Egypt, Feeding range, as an essential factor for evaluating its role inreducing the populations of plant pests, has been studied by numerous authors, e.g. Zaher et al. (1971), Soliman et al. (1976), Hanna et al. (1980), Yousef et al. (1982) \& EL-Bagoury \& Reda (1985). In some previous studies special attention was paid to the effectiveness of $A$. exsertus as an egg-predator of tetranychoid mites, e. g. ELBadry et al. (1969), Hafez et al. (1983) \& ELBagoury et al. (1989). It was found that feeding the predatory immatures on egg diets promoted faster development and a higher rate of oviposition than rearing on larvae or nymphs. Few biological studies with Agistemus species have been conducted (Zaher \& El Badry 1961, Osman \& Zaki 1986, Yue \& Childers 1994 \& Momen 2001. Agistemus exsertus is a common species found in Egypt where it was found preying on spider mites, eriophyid mites and scale insects (Zaher, 1986 \& Momen, 2001).

So, the objectives of this work was conducted to study the susceptibility of four soybean genotypes for mite infestation of two spotted spider mite, $T$. urticae and the effects of such genotypes on a predator mite, Agistemus exsertus, as well as study some biological aspects for both species. The results of this research can be used to optimize monitoring methods for establishing IPM strategies against this pest.

\section{MATERIALS AND METHODS}

Populations of the two-spotted spider mite, Tetranychus urticae Koch, and its predator mite, Agistemus exsertus Gonzalez, were determined on four soybean varieties including: Giza 35, Giza 111, Giza 82and Giza 22 during season 2016 at Menoufia Governorate, as well as study some biological aspects of both species. The experiments 
were carried out in a research field of Faculty of Agriculture, Menoufia University in Shebin El-Kom, Egypt, from June to September 2016. Four soybean varieties including: Giza 35, Giza 111, Giza 82and Giza 22 were planted in a randomized complete block design. An area of $350.5 \mathrm{~m} 2$ was divided into four blocks of $87.6 \mathrm{~m}$ and each block consisted of eight plots of $4.2 \times 2.6 \mathrm{~m}$.

Weekly samples of leaves were collected randomly in early morning from the soybean varieties. The population dynamics of $T$. urticae all stages and the predatory mite $A$. exsertus were recorded and monitored weekly from area of $25 \mathrm{~cm}^{2}$ of leaves.

\section{Collection of mites for biological studies:}

The spider mite Tetranychus urticae Koch and stigmaid mite Agistemus exsertus Gonzalez were collected from leaves and twigs of four soybean varieties, Glycine $\max (\mathrm{L}$.) Merrill, growing at the farm of the Faculty of Agriculture, Menoufia University in Shebin El-Kom district.

Copulated adult females of spider mite $T$. urticae and stigmaid mite $A$. exsertus were left to lay eggs on leaf discs of soybean varieties, and kept on moist cotton pad in Petri - dishes (15 cm in diameter) where suitable of moisture was daily supplied to keep leaf discs fresh for a longer time. Culture were provided with small pieces of cover slide glass and few cotton fibers as resting sites for egg deposition.

\section{Biological studies of Tetranychus urticae:}

Biology of the spider mite, T. urticae on different leaves of soybean varieties was carried out in the Laboratory. Fifty gravid females from mass culture were left on fresh leaf discs of soybean different varieties in Petri dishes for $24 \mathrm{hrs}$ in order to laid eggs then mites were removed from the leaves, eggs were counted and marked for subsequent development. The incubation period was calculated after egg hatching. The newly emerged hexapod larvae were carefully picked and kept singly on new leaf discs to complete development and examination were done twice a day. Similarly, the numbers of laid eggs per females were also recorded. Simultaneously, preoviposition, oviposition and post-oviposition periods were recorded as well as, male and female longevity was also recorded.

\section{Biological studies of Agistemus exsertus:}

Individuals of the stigmaid mite (male and female) were kept together for laying eggs on soybean leaves (Glycine max) infested with the two-spotted spider mite under laboratory conditions as prey. Eggs of the stigmaid mite were singly transferred to small $2 \mathrm{~cm}$ diameter discs of soybean leaves placed on cotton pads in $9 \mathrm{~cm}$-Petri dishes. Suitable moisture was daily maintained to the cotton layer. Leaf discs were replaced twice weekly to maintain freshness. Eggs were left to hatch and the incubation period was calculated. Immatures of $T$. urticae were introduced as prey for the predatory mite, A. exsertus Gonzalez. The consumed prey individuals were replaced daily by new ones. Fifteen replicates were used for each soybean variety. Observations on the development and reproduction were recorded twice a day.

Data was statistically analyzed by ANOVA test to compare means of each treatment (LSD test, where p> 0.05\%) using Costat Software (1990).

\section{RESULTS AND DISCUSSION}

\section{Susceptibility of soybean varieties to Tetranychus urticae infestation:}

Data in Table 1 revealed that Giza 35 variety was the most susceptible to $T$. urticae with significant difference to other varieties with mean number of infestation 11.89 individuals $/ 25 \mathrm{~cm}^{2}$ of leaves. It was 7.11 and 3.54 individuals $/ 25 \mathrm{~cm}^{2}$ of leaves for Giza 111 and Giza 82 without significant difference. Giza 22 recorded the lowest mean number of $T$. urticae 1.53 individuals $/ 25 \mathrm{~cm}^{2}$ without significant difference with Giza 82 but with significant difference with the other two varieties. This means that Giza 22 and Giza 82 haven't sufficient attract to phytophagous mite.

On the other hand the population dynamics of $T$. urticae cleared that infestation increased gradually from mid June to reach its maximum at the end of July then decreased gradually at the beginning of August to reach its minimum number at the beginning of September before the harvest time.

\section{Preference of soybean varieties to Agistemus exsertus:}

Data in Table 2 showed that the mean number of Agistemus exsertus was the highest on Giza 35 (2.46 individuals $\left./ 25 \mathrm{~cm}^{2}\right)$ followed by Giza $22(2.13$ individuals $/ 25 \mathrm{~cm}^{2}$ ), while Giza 82 and Giza 111 mean numbers were 1.99, and 1.91 individuals $/ 25 \mathrm{~cm}^{2}$. Statistical analysis cleared that no significant differences occurred between the mean numbers of $A$. exsertus on the four varieties, the high number on Giza 35 may be due to the abundance of its prey on this variety. As for population dynamics no individuals were recorded at the mid of June, then numbers slowly appeared at the end of June ( 0.5 individual $/ 25 \mathrm{~cm}^{2}$ ), increased gradually to reach 1.23 , 1.35 at the end of July, with the high number 2.38 individuals $/ 25 \mathrm{~cm}^{2}$ at the beginning of August. Numbers increased gradually during August to reach its maximum at the beginning of September with 7.56 individuals $/ 25 \mathrm{~cm}^{2}$. 
Table 1: Susceptibility of four soybean varieties to Tetranychus urticae infestation.

\begin{tabular}{|c|c|c|c|c|c|}
\hline \multirow{3}{*}{ Dates } & \multicolumn{4}{|c|}{ Mean No, of mites $/ 25 \mathrm{~cm}^{2}$ leaves } & \multirow{3}{*}{ Ave. } \\
\hline & \multicolumn{4}{|c|}{ Soybean Varieties } & \\
\hline & Giza 35 & Giza 111 & Giza 82 & Giza 22 & \\
\hline $15 / 6$ & 7.7 & 4.5 & 2.5 & 0.7 & $3.85^{\mathrm{c}}$ \\
\hline $22 / 6$ & 10.4 & 6.2 & 3.5 & 2.1 & $5.55^{\mathrm{bc}}$ \\
\hline $29 / 6$ & 12.7 & 7.9 & 3.7 & 1.3 & $6.40^{\mathrm{bc}}$ \\
\hline $6 / 7$ & 15.3 & 8.9 & 4.3 & 2.1 & $7.65^{\mathrm{ab}}$ \\
\hline $13 / 7$ & 15.9 & 9.3 & 4.6 & 1.6 & $7.85^{\mathrm{ab}}$ \\
\hline $20 / 7$ & 19.2 & 10.9 & 6.5 & 2.1 & $9.68^{\mathrm{a}}$ \\
\hline $27 / 7$ & 17.0 & 12.1 & 5.2 & 4.4 & $9.68^{\mathrm{a}}$ \\
\hline $3 / 8$ & 15.8 & 10.4 & 4.4 & 1.5 & $8.03^{\mathrm{ab}}$ \\
\hline $10 / 8$ & 13.8 & 7.7 & 3.9 & 1.5 & $6.73^{\mathrm{bc}}$ \\
\hline $17 / 8$ & 11.8 & 5.2 & 3.3 & 1.3 & $5.40^{\mathrm{bc}}$ \\
\hline $24 / 8$ & 9.8 & 6.2 & 2.8 & 0.9 & $4.93^{\mathrm{bc}}$ \\
\hline $31 / 8$ & 4.2 & 2.5 & 1.1 & 0.2 & $2.00^{\mathrm{c}}$ \\
\hline $7 / 9$ & 0.9 & 0.6 & 0.2 & 0.2 & $0.48^{\mathrm{d}}$ \\
\hline Total & 154.5 & 92.4 & 46 & 19.9 & \\
\hline Mean & $11.89^{\mathrm{a}}$ & $7.11^{\mathrm{b}}$ & $3.54^{\mathrm{bc}}$ & $1.53^{\mathrm{c}}$ & \\
\hline LSD & \multicolumn{4}{|c|}{4.32} & 3.76 \\
\hline
\end{tabular}

Table 2: Susceptibility of four soybean varieties to Agistemus exsertus.

\begin{tabular}{|c|c|c|c|c|c|}
\hline \multirow{3}{*}{ Dates } & \multicolumn{4}{|c|}{ Mean No, of mites $/ 25 \mathrm{~cm}^{2}$ leaves } & \multirow{3}{*}{ Ave. } \\
\hline & \multicolumn{4}{|c|}{ Soybean Varieties } & \\
\hline & Giza 35 & Giza 111 & Giza 82 & Giza 22 & \\
\hline $15 / 6$ & 0.0 & 0.0 & 0.0 & 0.0 & $0.0^{\mathrm{g}}$ \\
\hline $22 / 6$ & 1.0 & 0.0 & 0.5 & 0.5 & $0.5^{\text {efg }}$ \\
\hline $29 / 6$ & 1.0 & 1.2 & 1.0 & 0.5 & $0.93^{\mathrm{efg}}$ \\
\hline $6 / 7$ & 0.5 & 0.5 & 0.0 & 0.0 & $0.25^{\mathrm{fg}}$ \\
\hline $13 / 7$ & 0.5 & 1.0 & 0.5 & 0.5 & $0.63^{\text {efg }}$ \\
\hline $20 / 7$ & 1.0 & 1.5 & 1.2 & 1.2 & $1.23^{\mathrm{def}}$ \\
\hline $27 / 7$ & 1.5 & 1.2 & 1.5 & 1.2 & $1.35^{\mathrm{def}}$ \\
\hline $3 / 8$ & 2.5 & 1.75 & 2.5 & 2.75 & $2.38^{\mathrm{d}}$ \\
\hline $10 / 8$ & 1.8 & 2.0 & 1.4 & 1.6 & $1.70^{\mathrm{de}}$ \\
\hline $17 / 8$ & 2.5 & 2.0 & 2.1 & 2.2 & $2.20^{\mathrm{d}}$ \\
\hline $24 / 8$ & 4.2 & 3.2 & 3.5 & 4.2 & $3.78^{\mathrm{c}}$ \\
\hline $31 / 8$ & 6.0 & 4.75 & 4.5 & 5.2 & $5.11^{\mathrm{b}}$ \\
\hline $7 / 9$ & 9.5 & 5.75 & 7.2 & 7.8 & $7.56^{\mathrm{a}}$ \\
\hline Total & 32 & 24.85 & 25.9 & 27.65 & \\
\hline Mean & $2.46^{\mathrm{b}}$ & $1.91^{\mathrm{b}}$ & $1.99^{\mathrm{b}}$ & $2.13^{\mathrm{b}}$ & \\
\hline LSD & \multicolumn{4}{|c|}{1.02} & 1.23 \\
\hline
\end{tabular}

Table 3: Duration of Tetranychus urticae different stages fed on varieties of soybean leaves and number of deposited eggs/female under laboratory conditions.

\begin{tabular}{|c|c|c|c|c|c|c|}
\hline \multirow{2}{*}{\multicolumn{2}{|c|}{ Days }} & \multicolumn{4}{|c|}{ varieties of soybean } & \multirow{2}{*}{ LSD } \\
\hline & & Giza 35 & Giza 111 & Giza 82 & Giza 22 & \\
\hline \multirow{2}{*}{ Incubation } & $0^{\pi}$ & $3.2 \pm 0.10$ & $3.0 \pm 0.13$ & $3.3 \pm 0.42$ & $3.0 \pm 0.13$ & \\
\hline & o & $3.6 \pm 0.17$ & $3.3 \pm 0.18$ & $4.4 \pm 0.61$ & $3.3 \pm 0.41$ & \\
\hline \multirow{2}{*}{ Larva in days } & $0^{1}$ & $1.0 \pm 0.14$ & $1.0 \pm 0.07$ & $1.0 \pm 0.11$ & $1.2 \pm 0.52$ & \\
\hline & $q$ & $1.0 \pm 0.15$ & $1.5 \pm 1.06$ & $1.3 \pm 0.12$ & $1.6 \pm 0.07$ & \\
\hline \multirow{2}{*}{ Protonymph } & $\hat{0}$ & $1.5 \pm 0.20$ & $2.0 \pm 0.73$ & $2.0 \pm 0.13$ & $2.5 \pm 0.05$ & \\
\hline & $p$ & $1.5 \pm 0.20$ & $2.5 \pm 0.98$ & $2.2 \pm 0.57$ & $2.75 \pm 0.09$ & \\
\hline \multirow{2}{*}{ Deutonymph } & $0^{1}$ & $2.0 \pm 0.90$ & $2.5 \pm 0.27$ & $2.0 \pm 0.21$ & $2.2 \pm 0.14$ & \\
\hline & o & $2.0 \pm 1.02$ & $2.5 \pm 1.15$ & $2.0 \pm 0.74$ & $2.5 \pm 0.05$ & \\
\hline \multirow{2}{*}{ Life cycle } & $\frac{T}{0}$ & $7.7 \pm 0.41^{\mathrm{a}}$ & $8.5 \pm 2.02^{\mathrm{a}}$ & $8.3 \pm 0.25 a$ & $8.9 \pm 0.18^{\mathrm{b}}$ & 1.19 \\
\hline & $q$ & $8.1 \pm 0.25^{\mathrm{a}}$ & $9.8 \pm 0.75^{\mathrm{ab}}$ & $9.9 \pm 0.41^{\mathrm{ab}}$ & $10.2 \pm 0.75^{b}$ & 2.05 \\
\hline \multirow[b]{2}{*}{ Longevity } & $\hat{0}$ & $6.0 \pm 0.08^{\mathrm{a}}$ & $7.0 \pm 0.53^{\mathrm{ab}}$ & $7.75 \pm 0.47^{\mathrm{b}}$ & $7.5 \pm 0.41 \mathrm{a}^{\mathrm{b}}$ & 1.75 \\
\hline & 우 & $8.2 \pm 0.23^{\mathrm{a}}$ & $9.5 \pm 1.03^{\mathrm{ab}}$ & $10.0 \pm 2.81^{\mathrm{ab}}$ & $10.75 \pm 0.28^{b}$ & 2.55 \\
\hline \multirow{2}{*}{ Life span } & $\hat{0}$ & $13.7 \pm 0.47^{\mathrm{a}}$ & $15.5 \pm 0.47^{\mathrm{ab}}$ & $16.05 \pm 1.09^{b}$ & $16.4 \pm 0.75^{b}$ & 2.34 \\
\hline & p & $16.33 \pm 0.33^{\mathrm{a}}$ & $19.28 \pm 2.47^{\mathrm{ab}}$ & $19.86 \pm 1.06^{\mathrm{ab}}$ & $21.93 \pm 1.39^{\mathrm{b}}$ & 4.6 \\
\hline \multicolumn{2}{|c|}{ Number of eggs/female } & $31.0 \pm 1.13$ & $25.2 \pm 3.30$ & $22.75 \pm 1.43$ & $19.75 \pm 0.54$ & \\
\hline
\end{tabular}

Table 4: Some biological aspects of Agistemus exsertus on different varieties of soybean leaves under laboratory conditions.

\begin{tabular}{|c|c|c|c|c|c|c|}
\hline \multirow{2}{*}{ Biological aspects } & & \multicolumn{4}{|c|}{ Varieties of soybean } & \multirow{2}{*}{ LSD } \\
\hline & & Giza 35 & Giza 111 & Giza 82 & Giza 22 & \\
\hline \multirow{2}{*}{ Incubation period in days } & $\hat{0}$ & $5.24 \pm 0.27$ & $5.5 \pm 0.29$ & $5.0 \pm 0.42$ & $5.5 \pm 0.29$ & \\
\hline & q & $5.5 \pm 0.29$ & $6.0 \pm 0.25$ & $5.25 \pm 0.25$ & $5.25 \pm 0.25$ & \\
\hline \multirow{2}{*}{ Larva in days } & $\hat{0}$ & $4.50 \pm 0.5$ & $4.0 \pm 0.25$ & $3.75 \pm 0.5$ & $3.75 \pm 0.5$ & \\
\hline & q & $5.5 \pm 0.5$ & $5.75 \pm 0.25$ & $5.5 \pm 0.5$ & $5.0 \pm 0.58$ & \\
\hline \multirow{2}{*}{ Protonymph } & $\hat{0}$ & $3.5 \pm 0.25$ & $4.0 \pm 0.25$ & $3.5 \pm 0.48$ & $3.5 \pm 0.5$ & \\
\hline & q & $4.5 \pm 0.5$ & $5.0 \pm 0.58$ & $4.0 \pm 0.5$ & $4.5 \pm 0.25$ & \\
\hline \multirow{2}{*}{ Deutonymph } & $\hat{0}$ & $4.75 \pm 0.41$ & $4.75 \pm 0.25$ & $4.0 \pm 0.25$ & $4.75 \pm 0.5$ & \\
\hline & q & $4.5 \pm 0.48$ & $4.5 \pm 0.29$ & $4.75 \pm 0.41$ & $4.0 \pm 0.5$ & \\
\hline \multirow{2}{*}{ Life cycle } & $\frac{1}{0}$ & $17.99 \pm 0.85^{\mathrm{a}}$ & $18.25 \pm 0.48^{\mathrm{a}}$ & $16.25 \pm 0.63^{\mathrm{a}}$ & $17.5 \pm 0.63^{\mathrm{a}}$ & 2.0 \\
\hline & o & $20.0 \pm 0.61^{\mathrm{ab}}$ & $21.25 \pm 0.50^{\mathrm{a}}$ & $19.5 \pm 0.85^{\mathrm{ab}}$ & $18.75 \pm 0.85^{b}$ & 2.5 \\
\hline \multirow{2}{*}{ Longevity } & $\hat{0}$ & $18.0 \pm 1.25^{\mathrm{ab}}$ & $18.25 \pm 1.2^{\mathrm{a}}$ & $18.0 \pm 0.40^{\mathrm{ab}}$ & $17.0 \pm 0.58^{b}$ & 0.75 \\
\hline & p & $19.25 \pm 0.91^{\mathrm{a}}$ & $19.50 \pm 1.25^{\mathrm{a}}$ & $19.0 \pm 1.80^{\mathrm{a}}$ & $19.5 \pm 1.51^{\mathrm{a}}$ & 0.52 \\
\hline \multirow{2}{*}{ Life span } & $\sigma^{1}$ & $35.97 \pm 2.03^{\mathrm{a}}$ & $36.5 \pm 1.82^{\mathrm{a}}$ & $34.25 \pm 0.48^{a}$ & $35.0 \pm 0.48^{\mathrm{a}}$ & 2.28 \\
\hline & q & $39.25 \pm 1.48^{\mathrm{a}}$ & $40.75 \pm 1.35^{\mathrm{a}}$ & $38.5 \pm 0.58^{\mathrm{a}}$ & $38.25 \pm 1.35^{\mathrm{a}}$ & 2.60 \\
\hline Number of eggs/female & & $31.0 \pm 4.5$ & $36.0 \pm 0.91$ & $35.0 \pm 1.25$ & $34.0 \pm 4.1$ & \\
\hline
\end{tabular}


Some biological aspects:

Under laboratory condition the biology of both Tetranychus urticae and Agistemus exsertus was conducted.

\section{Biology of Tetranychus urticae:}

Table 3 showed some biological aspects of the tetranychid mite when fed on leaves of the four soybean varieties. Incubation period for males prolonged from 3 to 3.2 days without significant differences while it ranged from 3.3 to 4.4 days for female.

As for larval stage, the female larval stage was few longer (1: 1.6 days) than male (1: 1.2 days). Also protonymph and deutonymph periods were approximately the same for both sexes reared on different leaf varieties with shortest periods on Giza 35 and Giza 82. Life cycle of male was the shortest when reared on Giza35 with significant difference with other varieties, Giza 82 recorded the shortest male life cycle ( 8.3 days). As for females, the shortest life cycle was when reared on Giza 35 with significant difference with Giza 22 which recorded the longest life cycle for males and females respectively (8.1, 10.2 days).

The male life span ranged from 13.7 for Giza 35 to 16.4 days for Giza 22 with significant difference, also female life span ranged from 16.33 to 21.93 days with significant difference between Giza 35 and Giza 22 only.

The laid eggs per female was the lowest when reared on Giza 22 while was the highest when reared on Giza 35 (31.0 eggs/female).

Finally it could be concluded that Giza 35 was the most susceptible variety to tetranchid infestation as shown in field experiment and biology trials while other varieties were tolerate to infestation especially Giza 22 variety.

\section{Biology of Agistemus exsertus:}

Data in Table 4 cleared that the incubation period was about five days for Agistemus exsertus male to reach six days on Giza 111 for female. The host variety hasn't any effect on life cycle which prolonged from 16.25: 18.25 days for male and from 18.75: 21.25 days for female respectively.

The life span of the predatory mite was $34.25,38.5$ days for males and females reared on Giza 82, while it was $36.5,40.7$ days on Giza 111. The number of laid eggs per female ranged from 31.0: 36.0 eggs for different varieties. It was noticed that soybean varieties hasn't significant effect on the biology of the predatory mite Agistemus exsertus.

\section{REFERENCES}

Ahmadi M, Fathipour Y \& Kamali K 2006. Population growth parameters of two spotted spider mite, Tetranychus urticae (Acari: Tetranychidae) on different bean cultivars. Journal of Entomology Society Iran 22:1-10. (In Persian with English summary)

Brandenburg RL \& Kennedy GG 1987. Ecological and agricultural considerations in the management of twospotted spider mite (Tetranychus urticae Koch). Agricultural Zoology Review 2:185-236.

Costat Software 1990. Microcomputer Program Analysis, Version 4.20. CoHort Software, Berkely, CA., USA.

Dicke M 2000. Chemical ecology of host-plant selection by herbivorous arthropods: a multitrophic perspective. Biochemistry Systematics and Ecology. 28:601-617.

EL-Badry EA, Abo-Elghar MR, Hassan SM \& Kilany SM 1969. .Agistemus exsertus as a predator of two tetranychid mites. Annals of the Entomological Society of America. 62: 660--661.

EL-Bagoury ME \& Reda AS 1985. Agistemus exsertus Gonzalez (Acarina: Stigmaeidae) as a predator of the ploughman's spikenard gall mite, Eriophyes dioscoridis (Eriophyidae). Bulltein of the Entomological Society. 36: 571-576.

EL-Bagoury ME, Hafez SM,Heikal AM,Fahmy SA (1989)Biology of Agisternus exsertus as affected by feeding on two tetranychid mite species. Annals Agricultural Science. 34: 449-458.

Hafez SM, Rasmy AH \& ELSawi SA 1983. Influence of prey species and stages on predatory efficiency and developmentof the stigmaid mite Agistemus exsertus. Acarologia 24:281-283.

Hanna MA, Shereef GM \& Megali MK 1980. Effect of food type on longevity and fecundity of the predator mite Agistemus exsertus Gonzalez (Acarina: Prostigmata), with first description of its prelarva. Bulltein of the Entomological Society. 63: 57-62.

James DG \& Price TS 2002. Fecundity in twospotted spider mite (Acari: Tetranychidae) is increased by direct and systemic exposure to imidacloprid. Journal of Economic Entomology. 95(4):729-732.

Khanjani M 2005. Field crop pests (insects and mites) in Iran. Bu-Ali Sina University. Press, Hamadan (In Persian). 719 pp.

Marcic D 2003. The effects of clofentezine on lifetable parameters in two-spotted spider mite Tetranychus urticae. Experimental Applied of Acarology. 30(4):249-263.

Martinez MT, Jacas JA, Piolles JL \& Aucejo S 2006. Approaches for sampling the two spotted spider mite (Acari: Tetranychidae) on clementines in Spain. Journal of Economic Entomology. 
99: 1490-1499.

Momen FM .2001. Effects of diet on the biology and life tables of the predacious mite Agistemus exsertus (Acari: Stigmaeidae). Acta Phytopathologica Entomology Hungarica. 36: 1/2:173-178.

Osman AA \& Zaki AM 1986. Studies on the predation efficiency of Agistemus exsertus Gonzalez (Acarina, Stigmaeidae) on the eriophyid mite Aculops lycopersici (Massee). Anz FurSchadl Pflanz Umwelt. 59 (7):135-136.

Sabelis MW 1981. Biological control of two-spotted spider mites using phytoseiid predators. Part 1. Modelling the predator-prey interaction at the individual level. Pudoc, Wageningen, Agricultural Research. 910, 248 pp.

Skorupska A 2004. Resistance of apple cultivars to spotted spider mite, Tetranychus urticae Koch (Acarina, Tetranychidae) Part II. Infeluence of leaf pubescence of selected apple cultivars on fecundity of two-spotted spider mite. Journal of Plant Protection Research. 44(1):69-74.

Soliman ZR, Shehata KK \& Gomaa EA 1976. On the food range and economic importance of the predatory mite, Agistemus exsertus Gonzalez (Acari, Prostigmata). Anz FurSchadl Pflanz Umwelt 49: 87-90.

Van M, McMurtry JA \& Huffaker CB 1972. Ecology of tetranychid mites and their natural enemies: a review III. Biology, ecology and pest status, and host-plant relation of Tetranychids. Hilgardia 41:343-432.
Wermelinger B, Oertli JJ \& Baumga rrtner J 1991. Environmental factors affecting the life-tables of Tetranychus urticae (Acari: Tetranychidae) III. Host-plant nutrition. Experimental Applied of Acarology. 12:259-274.

Wilson LJ 1994. Plant-quality effect on life-history parameters of the two spotted spider mite (Acari: Tetarnychidae) on cotton. Journal of Economic Entomology. 87:1665-1673.

Yousef AA, Zaher MA \& AbdEl-Hafiez AM 1982. Effect of prey on the biology of Amblyseius gossipi El-Badryand Agistemus exsertus Gonzalez (Acarina: Phytoseiidae,Stigmaeidae). Journal of Applied Entomology. 93(1-5): 453-456.

Yue B \& Childers CC 1994. Effects of temperature on life table parameters of Agistemus exsertus Gonzalez (Acari: Stigmaeidae) and its attack rate on Panonychus citri eggs. International Journal of Acarology. 20(2): 109-113.

Zaher, MA 1986. Predaceous and non phytophagous mites in egypt (Nile valley and Delta) PI.480 Programme. USA Project No. EG. ARS. 30, Grant No FGEg. 139,pp. 567.

Zaher MA \& El-badry EA 1961. Life history of the predatory mite Agistemus fleschneri Summer and effect of nutrition on its biology. Bulltein of the Entomological Society. 45: 375 - 385.

Zaher MA, Afifi AM \& Gomaa EA 1971. Survey and biology of Agistemus exsertus Gonzalez in U.A.R., with description of the immature stages (Stigmaeidae: Acarina). Journal of Applied Entomology, 67: 272-279. 